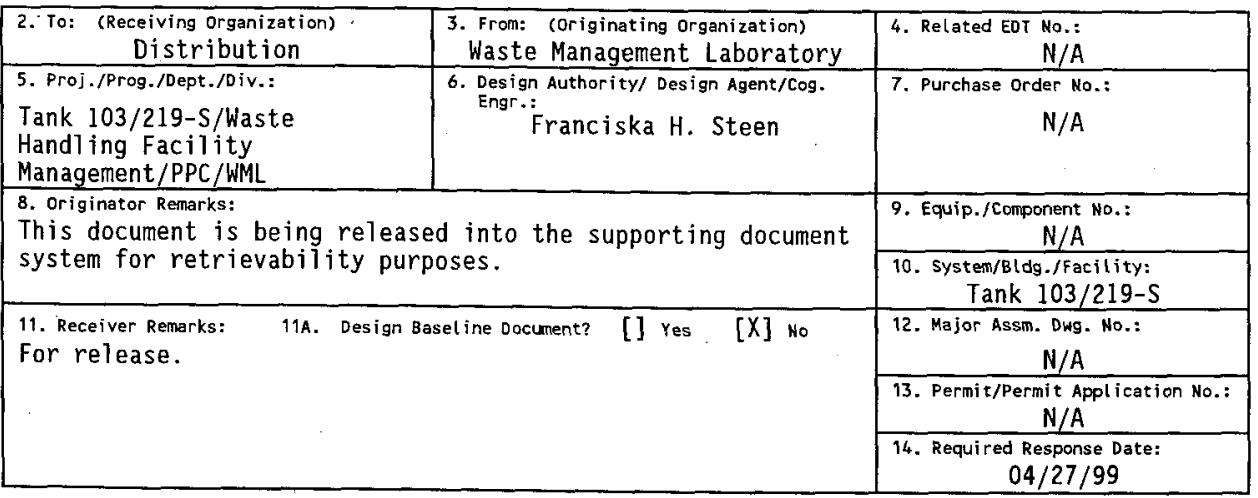

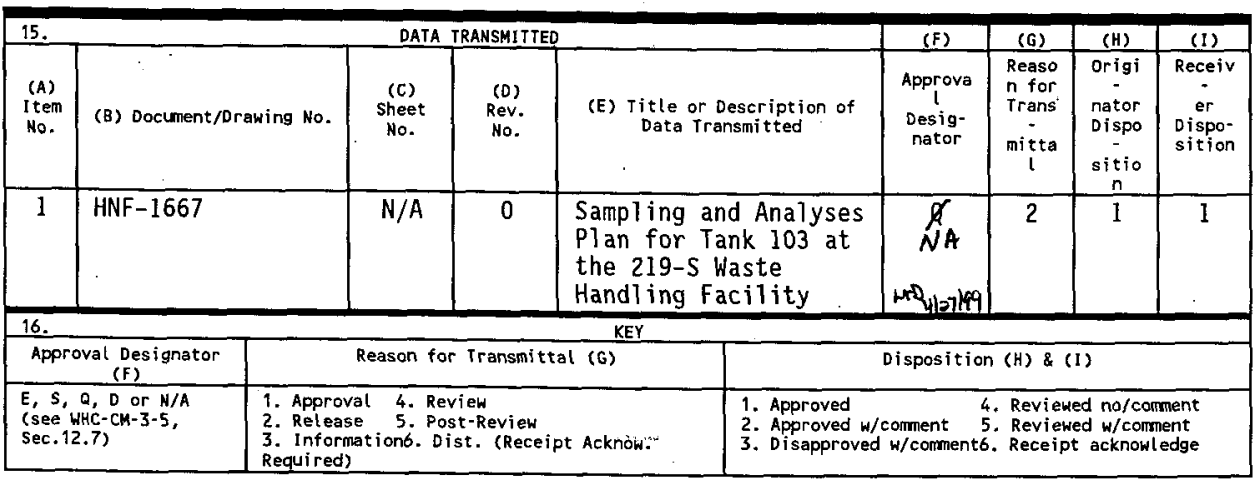

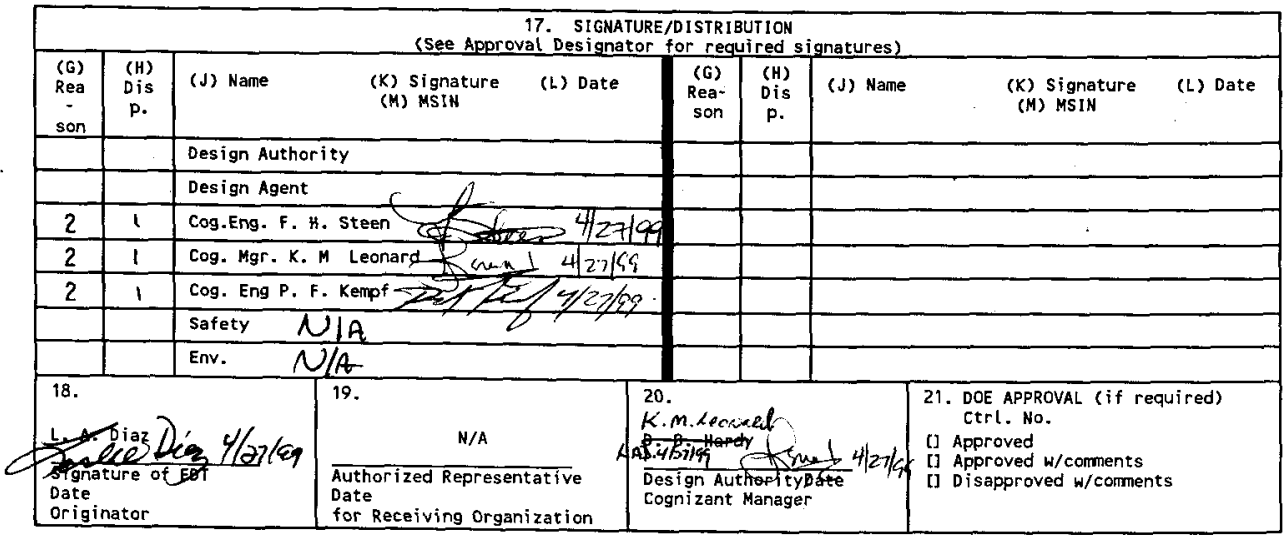




\section{Sampling and Analyses Plan for Tank 103 at the 219-S Waste Handling Facility}

Franciska H. Steen

Waste Management of Hanford, Inc., Richland, WA 99352

U.S. Department of Energy Contract DE-AC06-96RL13200

$\begin{array}{lll}\text { EDT/ECN: } & \text { EDT-626137 } & \text { UC: } 2070 \\ \text { Org Code: } & 31 \text { B00 } & \text { Charge Code: } 103423 \\ \text { B\&R Code: } & \text { EW 3120074 } & \text { Total Pages: } 7\end{array}$

Key Words: Tank 103, 219-S, Waste Handling Facility, Waste Handling, Analyses Plan,

Abstract: $N / A$

TRADEMARK DISCLAIMER. Reference herein to any specific commercial product, process, or service by trade name, trademark, manufacturer, or otherwise, does not necessarily constitute or imply its endorsement, recommendation, or favoring by the United States Government or any agency thereof or its contractors or subcontractors.

Printed in the United States of America. To obtain copies of this document, contact: Document Control Services, P.O. Box 950, Mailstop H6-08, Richland WA 99352, Phone (509) 372-2420; Fax (509) 376-4989.
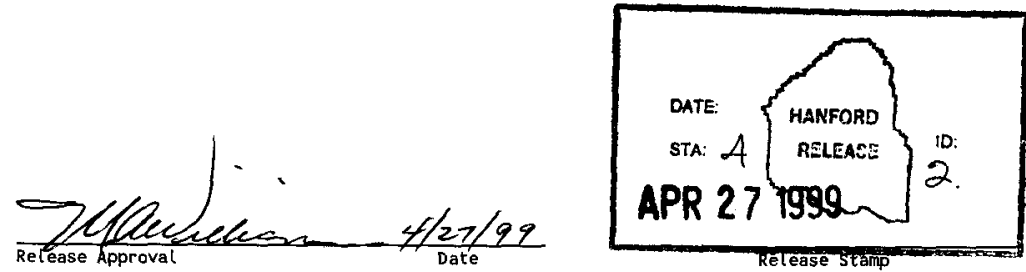

\section{Approved for Public Release}


HNF-1667 REV. 0

WASTE MANAGEMENT LABORATORY

\title{
SAMPLING AND ANALYSES PLAN FOR TANK 103 AT THE 219-S WASTE HANDLING FACILITY
}

\author{
Project Coordinator: Franciska H. Steen \\ Prepared for the U.S. Department of Energy \\ Office of Environmental Restoration \\ and Waste Management \\ by \\ 222-S Laboratory \\ Waste Management of Hanford, Inc. \\ P.0. Box 700 \\ Richl and, Washington
}


HNF-1667, Rev. 0

\section{Sampling and Analyses Plan for Tank 103 at the 219-S Waste Handling Facility}

\subsection{PURPOSE}

This document describes the sampling and analysis activities associated with taking a Resource Conservation and Recovery Act (RCRA) protocol sample of the waste from Tank 103 at the 219-S Waste Handling Facility treatment, storage, and/or disposal (TSD) unit at the 222-S Laboratory complex. This sampling and analyses is required based on negotiations between the State of Washington Department of Ecology (Ecology) and the Department of Energy, Richland Operations, (RL) in letters concerning the TPA Change Form M-32-98-01.

In a letter from George H. Sanders, RL to Moses N. Jaraysi, Ecology, dated January 28, 1999, it was noted that "Prior to the Tank 103 waste inventory transfer, a RCRA protocol sample of the waste will be obtained and tested for the constituents contained on the Part A, Form 3 Permit Application for the 219S Waste Handling Facility." In the April 2, 1999 letter, from Brenda L. Becher-Khaleel, Ecology to James, E. Rasmussen, RL, and William D. Adair, FDH, Ecology states that the purpose of these analyses is to provide information and justification for leaving Tank 103 in an isolated condition in the 219-S TSD unit until facility closure. The data may also be used at some future date in making decisions regarding closure methodology for Tank 103. Ecology also notes that As Low As Reasonably Achievable (ALARA) concerns may force deviations from some SW- 846 protocol. Every effort will be made to accommodate requirements as specified. Deviations from SW-846 will be documented in accordance with HASQARD.

\subsection{SITE DESCRIPTION AND BACKGROUND}

Tank 103 is located in the 219-S Waste Handling Facility TSD unit at the 222-S Laboratory complex. The 219-S TSD unit consists of four interconnected tanks. Currently the secondary containment at the 219-S is undergoing upgrades as part of TPA interim milestone M-32-98. Completion of this interim milestone includes the removal of Tank 103 from service. Tank 103 will be isolated and a small residual heel (less than $1 \%$ of the tank capacity) will be allowed to evaporate to dryness. RCRA closure of Tank 103 will not take place until RCRA closure of the 219-S Waste Handling Facility.

\subsection{CONSTITUENTS OF CONCERN}

Constituents of concern for sampling and analyses are based on the Part A, form 3 for the 219-S TSD unit. Table 1, attached, lists the dangerous waste codes as noted on the Part A, form 3 , the associated constituent of concern, and the SW- 846 method that will be used to analyze for the specific constituent.

The document Listed Waste History at Hanford Facility TSD Units, WHC-MR-0517, Revision 0 (June 1996 ) provides information on the specific sources that resulted in the F-listed waste codes. Only the specific solvent which may be found in the 219-S waste will be included as a constituent of concern. Also, WHC-MR-0518 notes that F039, Leachates, have not been accepted by the 222-S laboratory complex and therefore, F039 will not be included on the constituents of concern list. It has been determined that no 
F039 waste has been transferred to Tank 103, to date.

For waste codes, WP01, WP02, WT01, and WT02 no specific target compounds are identified. Analyses for semi-volatile and volatile organic compounds (SW-846 methods 8260 and 8270 ) are considered sufficient to detect to presence of any compounds associated with these waste codes. Therefore, since SW-846 methods 8260 and 8270 are being performed as part of this sampling and analyses effort, no additional analyses will be required.

In addition samples will be collected for Tank Waste Remediation System Waste acceptance criteria.

\subsection{PERFORMANCE STANDARD}

There are no specific performance standards associated with this sampling and analyses activity. Effort will be made to achieve the best detection limits possible for the analyses, however, ALARA concerns will limit the sample sizes and therefore will affect detection limits. The detection limits achieved will be noted on the final analytical report which will be maintained in the unit's operating files.

\subsection{SAMPLING ACTIVITIES}

The sampling activities will be conducted in accordance with the following 222-S Laboratory Complex procedures:

- LO-100-162, Sample and Treat Liquid Waste in Tank 103.

- LO-090-101, 222-S Laboratory Sample Receiving and Custodianship

All samples will be placed in new, EPA-approved, pre-cleaned polyethylene or plastic sample containers. The specific sample sizes are specified on the Sample Authorization Form (SAF) based on the contractual arrangements with the analytical laboratory conducting the analysis. The appropriate (i.e., compatible) containers and lids will be used for the samples. Each sample container will receive a unique sample number per the Hanford Environmental Information System. The appropriate sample preservation requirements are also specified on the SAF. The SAF will be prepared prior to sampling.

\subsection{QUALITY CONTROL}

The sample will be cooled to and maintained at 4 degrees Celsius. No additional preservations methods will be employed.

The following types of quality control samples will be collected: field blanks, and trip blanks. The trip blank will only be used in association with the organic analyses. These blanks are defined by HASQARD as follows:

- Trip Blank - A blank sample which travels with sample containers to the sampling site and returns unopened to the laboratory with the samples to be analyzed. The trip blank usually consists of carbon free, deionized water. The blank measures contamination during sample transport and typically only 
analyzed for volatile organic compounds.

- Field Blank - A blank sample prepared in the field at the sample collection site and returned to the laboratory with the samples to be analyzed. Tests for contamination from the atmosphere as well as those activities listed under trip blank.

\subsection{LABORATORY ANALYSIS}

Laboratory analysis will be performed to determine the concentration of the constituents of concern in the waste samples that are collected. SW-846 analytical methods (EPA 1986) will be used for the sample analysis whenever possible. Analyses will be performed using the methods listed in the attached table. ALARA requirements may result in deviations from any of these methods; any deviations will be noted and information maintained in the unit's operating record.

\subsection{DATA VALIDATION}

Data validation will be conducted. Validation will consist of the following:

- verification of required deliverables

- verification of requested versus reported analyses

- verification of lack transcription errors

- evaluation and qualification of results based on analytical holding times

- matrix spikes

- laboratory control samples (radiological samples only)

- laboratory duplicates

- analytical method blanks

- chemical recoveries

- tracer recoveries

- surrogate recoveries

- initial and continuing instrument calibrations

- counting instrument resolution checks

- calculation checks. 
Table 1: Constituents of Concern

\begin{tabular}{|c|c|c|}
\hline $\begin{array}{l}\text { Waste } \\
\text { Code }\end{array}$ & Constituent & Laboratory Procedure" \\
\hline D001 & IGNITABLE & LABORATORY SPECIFIC \\
\hline D002 & CORROSIVE & $\mathrm{pH}$ determination \\
\hline D003 & REACTIVE & CYANIDES/SULFIDES \\
\hline D004 & ARSENIC & 6010 \\
\hline D005 & BARIUM & 6010 \\
\hline D006 & CADMIUM & 6010 \\
\hline D007 & CHROMIUM & 6010 \\
\hline D008 & LEAD & 6010 \\
\hline 0009 & MERCURY & 6010 \\
\hline D010 & SELENIUM & 6010 \\
\hline D011 & SILVER & 6010 \\
\hline D018 & BENZENE & 8260 \\
\hline D019 & CARBON TETRACHLORIDE & 8260 \\
\hline D022 & CHLOROFORM & 8260 \\
\hline D028 & 1,2-DICHLOROETHANE & 8260 \\
\hline D029 & 1,1-DICHLOROETHYLENE & 8260 \\
\hline D030 & 2,4-DINITROTOLUENE & 8270 \\
\hline 0033 & HEXACHLOROBUTADIENE & 8270 \\
\hline D034 & HEXACHLOROETHANE & 8260 \\
\hline D035 & METHYL ETHYL KETONE & 8260 \\
\hline 0036 & NITROBENZENE & 8260 \\
\hline D038 & PYRIDINE & 8260 \\
\hline 0039 & TETRACHLOROETHYLENE & 8260 \\
\hline DO40 & TRICHLOROETHYLENE & 8260 \\
\hline D041 & 2,4,5-TRICHLOROPHENOL & 8270 \\
\hline 0043 & VINYL CHLORIDE & 8260 \\
\hline WPO1* & HALOGENATED HYDROCARBONS & $8260 / 8270$ \\
\hline WPO2" & HALOGENATED HYDROCARBONS & $8260 / 8270$ \\
\hline WTO1* & EHW & $8260 / 8270$ \\
\hline WTO2 $2^{\text {nr }}$ & DW & $8260 / 8270$ \\
\hline $\mathrm{F}^{0} 01^{-\infty}$ & 1,1,1-TRICHLOROETHANE & 8260 \\
\hline $\mathrm{F} 002^{-m}$ & METHYLENE CHLORIDE & 8260 \\
\hline \multirow[t]{2}{*}{ F003" } & ACETONE & 8260 \\
\hline & METHYL ISOBUTYL KETONE & 8260 \\
\hline F004"m & CRESOLS AND CRESYLIC ACID & 8270 \\
\hline F005 & METHYL ETHYL KETONE & 8260 \\
\hline \multirow[t]{8}{*}{ F039"* } & LEACHATE - NON APPLICABLE & $\mathrm{n} / \mathrm{a}$ \\
\hline & AMMONIA & LABORATORY SPECIFIC \\
\hline & ION CHROMOTOGRAPHY & LABORATORY SPECIFIC \\
\hline & AM241 & LABORATORY SPECIFIC \\
\hline & GEA & LABORATORY SPECIFIC \\
\hline & PU239 & LABORATORY SPECIFIC \\
\hline & SR90 & LABORATORY SPECIFIC \\
\hline & ICP/MS & LABORATORY SPECIFIC \\
\hline
\end{tabular}


Table 1: Constituents of Concern Continued

TDS

TSS

TOTAL ALPHABBETA

SPECIFIC GRAVITY

TOTAL ORGANIC CARBON

HYDROXIDE

TGA

DSC
LABORATORY SPECIFIC

LABORATORY SPECIFIC

LABORATORY SPECIFIC

LABORATORY SPECIFIC

LABORATORY SPECIFIC

LABORATORY SPECIFIC

LABORATORY SPECIFIC

LABORATORY SPECIFIC

- SW-846 procedure or equivalent, unless otherwise noted. SW- 846 method deviations are noted in the laboratory specific procedures.

- Analyses for semi-volatile and volatile organic compounds (SW-846 methods 8260 and 8270) are considered sufficient to detect to presence of any compounds associated with these waste codes.

- Specific constituent of concem based on WHC-MR-0517, Revision 0, Listed Waste History at Hanford Facility TSD Units, June 1996. To date, no F039 waste has been transferred into Tank 103, therefore no analyses is applicable. 


\section{DISTRIBUTION SHEET}

\begin{tabular}{|c|c|c|c|}
\hline \multirow{2}{*}{$\begin{array}{l}\text { To } \\
\text { Distribution }\end{array}$} & \multirow{2}{*}{\multicolumn{2}{|c|}{ From }} & Page 1 of 1 \\
\hline & & & $04 / 27 / 99$ \\
\hline \multirow{2}{*}{\multicolumn{3}{|c|}{$\begin{array}{l}\text { Project Title/Work Order } \\
\text { HNF-1667 Rev. } 0 \text { "Sampling and Analyses Plan for Tank } 103 \text { at the } \\
219-S \text { Waste Handling Facility" }\end{array}$}} & EDT N0.: EDT-626137 \\
\hline & & & ECN NO.: N/A \\
\hline & MSIN & $\begin{array}{l}\text { Text With } \\
\text { a)1 Attach }\end{array}$ & $\begin{array}{l}\text { EDT/ECN } \\
\text { ONLY }\end{array}$ \\
\hline
\end{tabular}

Waste Management of Hanford, Inc.

L. A. Diaz

J. E. Hyatt

P. F. Kempf

A. L. Prignano

F. H. Steen

LTIC

T6-12

T6-14

T6-20

$\mathrm{H} 6-24$

T6-12

T6-03

$$
X *
$$

$X$

$x$

$\underset{X}{x}$

$\mathrm{X}$

T6-14 $X$

Waste Management Northwest

K. M. Leonard

$\mathrm{DOE} / \mathrm{RL}$ Reading Room

$\mathrm{H} 2-53$

$\mathrm{X}$

* Needs only releasing paperwork, not a copy of the released document. 